\title{
ANTECENDENT AND CONSEQUENCE DESTINATION INNOVATION
}

\author{
Windi NR WARDANI \\ Sultan Agung Islamic University (UNISSULA), Faculty of Economics, Department of Management, \\ Jl. Raya Kaligawe Km.4 Po.Box. 1054/SM Semarang Indonesia, e-mail: bilqin.o9@gmail.com

\begin{abstract}
WIDODO $^{*}$
Sultan Agung Islamic University (UNISSULA), Faculty of Economics, Department of Management, Jl. Raya Kaligawe Km.4 Po.Box. 1054/SM Semarang Indonesia, e-mail: widodo@unissula.ac.id
\end{abstract}

Citation: Nr Wardani, W. \& Widodo (2020). ANTECENDENT AND CONSEQUENCE DESTINATION INNOVATION. GeoJournal of Tourism and Geosites, 28(1), 9-20. https://doi.org/10.30892/gtg.28101-448

\begin{abstract}
This article aim of developing the competitive advantage of Tourism Competitive Advantage which emphasizes the development of tourism in knowledge quality and destination innovativeness by increasing entrepreneurship learning. The sampling method is using purposive sampling technique, meaning that based on population characteristics that is the leader of the tour the owner is government or private and operates for at least 5 years. Then the sample size of 120 out of 200 population. The analysis technique uses Strutural Equation Model with AMOS software. The results of this study indicate that four hypotheses are proposed, three are significant and one hypothesis is not significant. Therefore, the tourm competitive advantage development model can be improved through innovative destinations that are built with indicators of assimilation, differentiation and integration.
\end{abstract}

Key words: Destination innovation, tourism competitive advantage, knowledge quality, entrepreneur learning

\section{INTRODUCTION}

The condition of leisure economy has been a trend for the community to switch from buying products to buying "experience". From this point, tourism becomes a very prospective sector to be developed. Tourism is one of the driving forces of business in the service sector. Compared to other sectors, tourism has had supporting potentials. The tourism industry triggers an increase for the state revenue. In a dynamic global tourism industry, destination competitiveness turns to be very important to improve its performance, facilitate more effective destination management as well as to inform overall sustainable economic development (Chin et al., 2017). The attractiveness of a 
destination is also considered as an amalgamation of tourism products which offer integrated experiences and memories for tourists (Chin et al., 2017). Thus, tourism competitive advantage is something strategic and substantive. Competitive advantage is closely related to the ability of a destination to use available resources which involve the distribution of resources (Crouch \& Ritchie, 1999). Tourism Competitive advantage refers to the ability of a destination to attract and satisfy potential tourists (Hall, 2019).

Innovation is considered very important in the development of the industry to achieve sustainable competitive advantage, yet innovation in tourism has remained a topic which is still being researched and innovation is undervalued in tourism (Zehrer, 2016, Monteagudo \& Maria, 2018; Politis \& Jonas, 2015; Cowdean et al., 2018; Gjedia \& Ndou, 2019). The research gaps related to innovation in the tourism industry lead to insufficient understanding of important elements in innovation for the tourism business (Gjedia \& Ndou, 2019). Destination innovation research is a new phenomenon. The tourism industry is different from manufacturing and many other services, and destination innovation must be based in part or in full on the various angles and other research instruments. Therefore, a new methodology must be developed regarding with destination innovation research (Hjalager, 2010). Schumperian's approach to innovation emphasizes the role of visionary entrepreneurs (Sundbo et al., 2007).

There are challenges in adopting this approach in tourism, recalling that SMEs are largely widespread and have high in-and-out streams. What motivates entrepreneur innovators and what knowledge they carry are very essential to consider. Knowledge quality helps companies do better jobs, develop useful products or services, reduce costs and improve performance (Dong et al., 2011). Since organizations are required to improve the quality of knowledge, knowledge quality has been an important issue in creating competitive advantages and dealing with a rapidly changing business environment.

The perspective of using knowledge means that knowledge is not only obtained but also integrated to all different sources of special knowledge (Majchrzak et al., 2004). Human resources are willing to spend time and energy to pursue knowledge if the knowledge seems to have value and can cause benefits (Davenport \& Prusak, 1998).

The study of Valae \& Rezaei (2016) explains that the quality of knowledge is a new concept and there is little research in the tourism industry. Entrepreneurship learning, therefore, is strategic in developing organizational performance. Entrepreneurship learning problems are not only related to entrepreneurs who are learning during the process of exploring and exploiting entrepreneurial opportunities to creating new businesses or existing company management, but also, more importantly, specific learning processes which occur (Wang \& Chugh, 2014). In short, how the learning process takes place and when learning takes place are very important to understand the entrepreneurial process. Entrepreneurship is a learning process and entrepreneurial theory strongly needs learning theory. The consequence of increasing organizational learning is the increasing number of individuals behaving proactively. The study of Stinglhamber et al., (2015), however, recommends that future studies be assessed on individual factors, so as to improve organizational performance comprehensively.

\section{LITERARY REVIEW}

\section{Tourism Competitive Advantage}

The sustainable competitive advantages are the results provided by rare, valuable and unique human resources; customer relations, and systems which serve organizations with a position of on going competition (Abreu et al., 2016). The basic thought of creating a competitive strategy starts from how the business will be developed, what exactly the goal is and what policies will be needed to achieve that goal (Musetescu, 2013). The 
concept of sustainable development is adopted into the concept of developing sustainable tourism development (Armenski et al., 2018). Sustainable tourism development is defined as a tourism development process that is oriented to the preservation of resources needed for future development and does not have a negative impact on the development of local culture, as well as the existence of such cultures must be maintained for future generations (Aydin et al., 2018). Tourism Competitive advantage refers to the ability of a destination to attract and satisfy potential tourists (Hall, 2019). Tourism Competitive advantage is also the ability of objects and the attraction of tourist destinations to maintain market position, share and improve it in the long term (Abreou et al., 2015).

Tourism Competitive advantage is the ability of objects and attractiveness of tourist destinations to preserve existing natural capital for future generations (Wong, 2015), create and integrate value-added products that maintain their resources (Al Bayrak et al., 2018) and when referring to competitiveness, tourism destinations must also include the sustainability of local resources to ensure maintenance of long-term success and the achievement of equitable resource returns which are used to satisfy all stakeholders (Martinez et al., 2015) and competitiveness refers to the ability of tourism destinations to improve high living standards for the surrounding community (Aydin et al., 2018). In strategic management, the main objective of all processes carried out by the organization is to achieve sustainable competitive advantage (Añaña et al., 2018).

The development of the tourism sector must realize sustainable competitive advantage as the main destination with the main variables such as Value of Destinations, Tourism Destinations, tourist destinations that are not owned by other regions and able to become regional tourism identities (Corte \& Massimo, 2016). The three general dimensions of Tourism Competitive Advantage include the dimensions of attractiveness associated with the ability of destinations to attract and satisfy potential tourists; the economic dimension which is related to the ability to change favorable positions into economic benefits with the ultimate goal of increasing the wealth of the local population; and finally the sustainability / sustainability dimension that is related to the long-term sustainability of a destination (Abreu et al., 2015). Thus, it can be concluded that the Tourism Competitive advantage covers the ability of objects and the attractiveness of tourist destinations in maintaining the sustainability of local resources, creating and integrating value-added products, raising high living standards for surrounding communities and attracting and satisfying potential tourists. Tourism Competitive advantages must be economically, ecologically, socially, culturally, and politically sustainable. The indicators in this study are environmental sustainability, the welfare of the surrounding community (social wealth), visitor satisfaction, and attractiveness (Abreau, 2015).

\section{Destination Innovativeness}

Destination innovativeness is the sustainable competitiveness of destination objects and tourist attractions in facing the competition and collaborating with similar objects to synergize strategies to attract the flow of tourist visits (Zach \& Hill, 2017). The tourism sector and industry must have uniqueness (differentiation) that is not owned by other regions and in order to establish this uniqueness, tourism marketers must have a high strategy and innovative power (Fatima et al., 2017). In tourism and hospitality companies, innovation has proven to be more complex than general management (Kalmuenzer \& Andreas, 2018). Hjalager (2010) states that innovation in tourism occurs in the form of products / services, processes, managerial, marketing or institutional innovation. There remains little doubt, however, about the relevance of innovation for the survival of tourism and hospitality companies (Hjalager, 2010). Previous researches have so far largely concentrated solely on exploring the innovative capabilities of tourist destination actors, without testing the effect on the importance of innovation as a 
competitive advantage (Kalmuenzer \& Andreas, 2018). The current paradigm shift in the meaning of innovation is compared with the development of product packaging, distribution, marketing and strategy (Martinez et al., 2015). There are many methods used to classify destination innovativeness but generally destination innovativeness revolves around the emphasis on object design and tourist attraction, market research, and advertising and promotion (Hjalager, 2010), Destination Innovativeness is an important component in achieving sustainable excellence in the tourism sector for it reflects the important means of which organizations are able to capture new opportunities (Lee, 2016). Destination Innovativeness reflects the tendency of a tourist destination in supporting new ideas, updates, experimentation, and creative processes that can produce new products, services, or playground developed (Kallmuenzer \& Andreas, 2018).

Destination Innovativeness is defined as the willingness of tourism companies to innovate (Thu et al., 2018). Destination Innovativeness is defined as a company's tendency to engage in and support new ideas, novelty, experiments, and creative processes which can create new products, services, or technological processes (Demet, 2019) Destination Innovativeness is generally measured by innovations that occur in tourism which covers tourism products / services, processes, managerial, marketing or innovation of tourist destinations (Kallmuenzer \& Andreas, 2018). It can be concluded that Destination Innovativeness is defined as the willingness of tourist destinations to engage in and support new ideas, novelty, experiments, and creative processes which can create new products, services, or new technological processes in existing playing fields. Destination Innovativeness is measured by indicators of assimilation, differentiation, inversion, and integration (Gallouj \& Savona, 2010). The results of Foroudi et al., (2017) stated that the capability of innovation is one of the triggers in achieving sustainable competitive advantage. Therefore a proposition can be arranged as follows.

H1: Destination innovativeness was developed as an antecedent of increasing tourism competitive advantage.

\section{Knowledge Quality}

Knowledge plays an important role in innovation (Hjalager, 2002; Lawson \& Samson 2011). Innovation is not possible without proactive resources for cooperation and innovation and adequate technology and technological knowledge (Nieves \& Gonzalo, 2018). Transfer of knowledge is very essential for organizations because it tends to be global in nature to utilize diverse labor costs, expertise, and access to world markets (Lane \& Lutbatkin, 1998). Knowledge transfer, however, is a very difficult process to achieve and knowledge transfer might fail for reasons ranging from the quality of the relationship between the donor and the recipient group to the characteristics of the knowledge transferred. The transfer of knowledge taking place between groups has relatively higher quality from the knowledge possessed by new members compared to the knowledge that is in a group although the decision to receive knowledge from new people is influenced by many factors, such as newcomer accommodation or conflict avoidance modes (Lane \& Lutbatkin, 1998). In the previous literature on knowledge transfer, it was argued that the higher the quality of knowledge, the more complex it is embedded in the reservoir of knowledge of the company which includes people, tasks, tools, and networks.

The complexity of knowledge quality is a source of unique and imitable assets because high-quality knowledge is formed by the process of "learning by doing" in organizations, and the key to its creation is the accumulation of experience and knowledge (Nonaka \& Takeuchi, 1996). High-quality knowledge acquisition is needed for innovation where suppliers and target companies share the same knowledge, while acquiring moderate amount of knowledge is needed for more innovation in fields unknown to supplier companies (Han et al., 2018). Innovation is considered very important in the development of the 
industry to achieve sustainable competitive advantage but innovation in tourism has remained a topic that is still being researched and innovation undervalued in tourism (Zehrer, 2016, Monteagudo \& Maria, 2018; Politis \& Jonas 2015; Cowdean et al., 2018; Gjedia \& Ndou, 2019). Research gaps related to innovation in the tourism industry lead to insufficient understanding of important elements of innovation in the tourism business (Gjedia \& Ndou, 2019). Innovation is also defined as the openness of someone towards a new technology system, new information or experience and in the tourism and hospitality industry, and innovation is a positive factor which affects individuals to become more open to new technologies and becomes less complex to adopt (Fatima et al., 2017). Innovation in the tourism sector is a major topic in the literature, where, from a theoretical point of view, it has been suggested that innovation plays an undeniable role in the tourism industry. New, innovative and useful knowledge for the organization / institution / system shall meet the requirements of quality knowledge (Chow \& Chan, 2008). Knowledge that is used repeatedly for the formation of other new knowledge is high-quality knowledge (Waheed \& Kiran, 2014). Knowledge quality is defined as an acquisition of useful and innovative knowledge (Waheed et al., 2016).

Knowledge quality is defined as the extent to which awareness and understanding of ideas, logic, relationships, and appropriate conditions can be used, relevant, valuable for context, and applicably adapted (Widodo et. al. 2015). Knowledge can be innovative for a system or organization, but if that knowledge is not useful for organizational development or new innovation in the organization, then it cannot meet the knowledge quality criteria (Chouch \& Ricci, 2015). Knowledge quality can be concluded as knowledge that is used and has adaptability quality, development quality, and is easy to apply.

Linkages, wealth, and knowledge strategies and processes are used to measure knowledge quality (Chow \& Chan, 2008). New, innovative and useful knowledge for the organization / institution / system meets quality knowledge requirements (Waheed and Kiran, 2014). Knowledge quality is measured by using dimensions of usability and innovation (Waheed \& Kiran, 2014). Adaptability, expandability, and applicability are other important features of quality knowledge (Nonaka \& Takeuchi, 1995; Yoo et al., 2011). Knowledge which cannot be applied by individuals in real life because of its practical use is not quality knowledge. Knowledge quality enables organizations to adapt, develop, and easily apply knowledge in order to enhance effective actions and overcome uncertainties by adjusting their knowledge for flexible, broad and easy situations (Widodo et al., 2015). Thus, the indicators used in this study are Adaptable, Applicable, Expandable, True, Innovative, and Justified (Waheed \& Kiran, 2014). Knowledge is a competitive instrument in the tourism industry which is greatly important to understand knowledge as a resource and competitive advantage (Monteagudo \& Maria, 2018). Therefore, a proposition can be set up as follows.

H2: Knowledge quality is developed as an antecedent to increase destination competitive advantages.

Knowledge plays an important role in innovation (Monteagudo \& Maria, 2018). Innovation in organizations is not possible without the existence of highly qualified human resources, who are proactive in cooperation and innovation, and without technology and adequate technological knowledge and market knowledge, it seems hard to do so. Thus, a proposition can be arranged as follows.

H3: Knowledge quality is developed as a supporter to the increasing destination innovativeness.

\section{Entrepreneur Learning}

Entrepreneurship is very closely related to innovation because it involves creation of something new or in new ways: new combinations, new production methods, new 
businesses, new markets and new wealth (Corte \& Massimo 2016). The entrepreneurial spirit has an important role in the tourism industry (Hunter \& Jonathan, 2018). The importance of entrepreneurship in the tourism industry has been largely underestimated or misunderstood (Deale, 2016) whereas entrepreneurship plays a major role in the development of tourist destinations, and entrepreneurial figures have not yet been the subject of adequate research (Gjedia \& Ndou, 2019). Cowdean et al., (2018) defines entrepreneurship as a learning process derived from experience and innovation. Entrepreneurship describes a new combination process in a company to create new products, new processes, product quality, new organizational formats and so on to answer market challenges (Politis \& Jonas, 2015). Innovation for entrepreneurship in tourism has become a new approach that was ignored in the research agenda in early time and ensures that there is still a lack of research on entrepreneurship in the field of hospitality and tourism management (Monteagudo \& Maria, 2018). Today entrepreneurship is considered a process which focuses on innovation, growth and uniqueness (Gartner, 1990).

In the macroeconomic point of view, the literature has shown a positive correlation among innovation, entrepreneurship and economic growth (Monteagudo \& Maria, 2018; Politis \& Jonas, 2015; Cowdean et al., 2018; Gjedia \& Ndou, 2019). Entrepreneurship is a missing link in economic growth because entrepreneurship is a form of knowledge from academics, universities and forms of commercialization of ideas (Hunter\& Jonathan, 2018). Entrepreneurship is very closely related to innovation because it commonly involves creation of something new or in new ways: new combinations, new production methods, new businesses, new markets and new wealth (Brush et al., 2003). Entrepreneurship is a factor that supports innovation and an important determinant in the competitiveness of the tourism sector, because it promotes the transfer of products (Hjalager, 2010).

Entrepreneur Learning has been studied since a century ago, and has several learning characteristics which are different from others (Matthew et al., 2015). Organizational learning has a very positive influence on knowledge sharing behavior (Kamya et al., 2011). Entrepreneurial Learning is one variation of the experiential and cognitive processes used to obtain, maintain, use and share entrepreneurial knowledge (Matthew et al., 2015). The learning process of exploring and exploiting existing opportunities enable an entrepreneur to respond towards market conditions and determine renewal strategies which will be carried out as a step of innovation (Sheng \& Chien, 2016). Entrepreneurship learning can facilitate the development of one's dynamic capabilities in adapting to market changes and making appropriate innovations (Fernández \& Alegre, 2015). A successful entrepreneur always has particular behavior of being glad to share ideas and information with others, receives constructive suggestions and criticism, and provides coaching clinics to other entrepreneurs to form a strong network of cooperation (Matthew et al., 2015).

The results of Ernest's research, Matthew et al. (2015) stated that entrepreneurial learning aims to enhance creativity, have high innovation power, entrepreneurial spirit, become someone who has the ability to solve problems effectively, communicate and have networks as well as become leaders (Chowdean et al., 2018). Many scholars have described tourism as a system rather than industry (Deale \& Seung, 2018) and include attractions, services, promotions, information and transportation as the tourism supply sides (Wang et al., 2018), with retail businesses serving tourists, including tourism destination assets that is owned and operated by tourism entrepreneurs, which is an important part of the sector.

Therefore, given the role of entrepreneurs, who may be key stakeholders such as hoteliers or restaurant owners or stakeholders such as retail business owners and tourism actors, their insights about education for businessmen in the hospital and tourism sector are important (Neck et al., 2018). Entrepreneur learning in tourism is measured by indicators of creativity, risk-taking opportunities, and understanding a sense of tourism 
community (Deale, 2016). Entrepreneur learning can be concluded as a learning process to improve the ability of capturing career opportunities, creativity, risk taking and responsibility, and providing the technical and business skills needed to start a business.

Entrepreneur learning includes a series of learning processes and skills such as the ability to recognize personal opportunities of each individual, the ability to utilize existing abilities by generating new ideas and using the necessary resources, the ability of individuals to create, act, take risks by carrying out new adventures and the ability to think in creative and critical ways (Deale, 2016). Entrepreneurial activities positively give impacts on the innovation of entrepreneurs in the tourism sector (Yang et al., 2018). Entrepreneur learning is a learning process and knowledge-producing skills (Gjedia \& Ndou, 2019). Therefore, propositions can be arranged as follows.

H4: The increase in entrepreneur learning will lead to the increase of knowledge quality. Based on the complete and in-depth literature, a research model can be developed as in Figure 1.

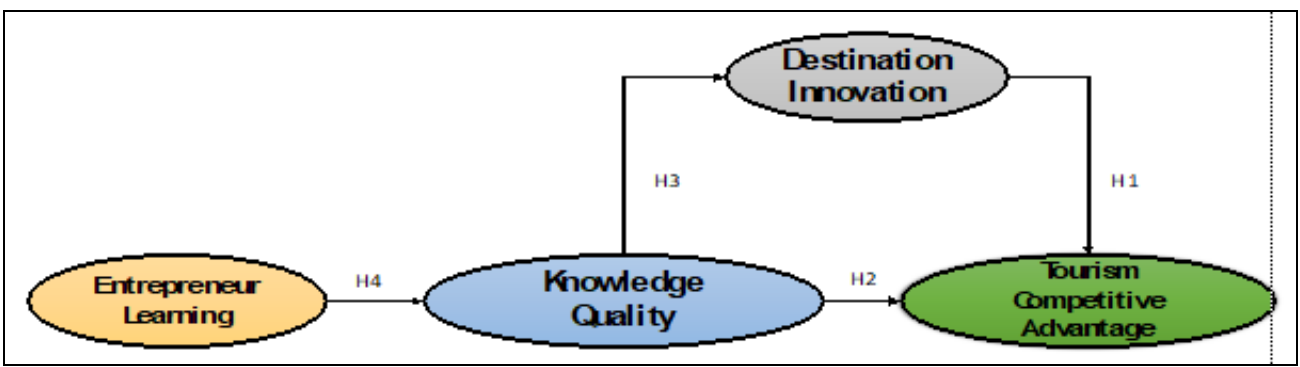

Figure 1. Empirical model of research

\section{RESEARCH METHOD}

\section{Sample}

The population of this study is the tourism industry in Central Java Province with 200 possessed by the government and private owners. The sampling method used was purposive sampling technique, meaning that it is based on the characteristics of the population, namely tourism leaders in Central Java Province by location and a minimum of 5 years of operation. The sampling size refers to Hair et al. (1996), which is 120 respondents.

\section{Measurement of Variables}

The entrepreneur learning indicator refers to the Deale study (2016) which involves recognizing opportunities, generating new ideas and taking risks. Furthermore, the quality indicator knowledge includes: adaptable, applicable and expandable (Waheed \& Kiran, 2014). Then, destination innovativeness involves assimilation, differentiation, integration (Gallouj \& Savona, 2010) while Tourism Competitive advantages include environmental sustainability, social wealth and attractiveness (Abreau, 2015).

The variables were measured with questionnaire by using likert-scale with answer scale of 1 to 5 . The scale represented the rating from 'strongly disagree' to 'strongly agree'. Table 1 shows the results of validity and reliability test and a loading factor value above 0.7 (Sekaran, 2003) and a minimum reliability value of 0.6 (Hair et al., 2010). Therefore, it can be concluded that the instrument has the validity and reliability.

\section{RESULT}

\section{Goodness of fit}

The empirical model test used Structural Equation Modeling. The model indicates that Chi-square $=58.000$ with probability value of $0.204 ; \mathrm{GFI}=0.928, \mathrm{AGFI}=0.888$ and 
TLI $=0.986$, while value of RMSEA $=0.037$. The result of the model is a Fit. Based on statistical analysis, the results of this study indicate conformity with the required standard values. As shown in Figure 2 was the results of the Full Analysis Model.

Table 1. Validity and Reliability Test

\begin{tabular}{|c|l|l|c|c|}
\hline No & \multicolumn{1}{|c|}{ Variable } & \multicolumn{1}{|c|}{ Indicator } & Loading Factor & Reliability \\
\hline \multirow{2}{*}{1} & \multirow{2}{*}{ Entrepreneur learning } & a) Recognizing opportunity & 0.85 & 0.72 \\
& & b) Creating new ideas & 0.83 & \\
& & c) Dare to take risk & 0.82 & \\
\hline \multirow{2}{*}{2} & \multirow{2}{*}{ Knowledge quality } & a) Adaptable & 0.86 & 0.69 \\
& & b) Applicable & 0.77 & \\
\hline \multirow{2}{*}{3} & \multirow{2}{*}{$\begin{array}{l}\text { Destination } \\
\text { innovativeness }\end{array}$} & a) Assimilation & 0.86 & 0.79 \\
& b) Differentiation & 0.73 & \\
\hline \multirow{2}{*}{4} & Tourism Competitive & c) Integration & 0.87 & 0.76 \\
& advantage & a) Environmental sustainability & 0.90 & \\
\hline
\end{tabular}

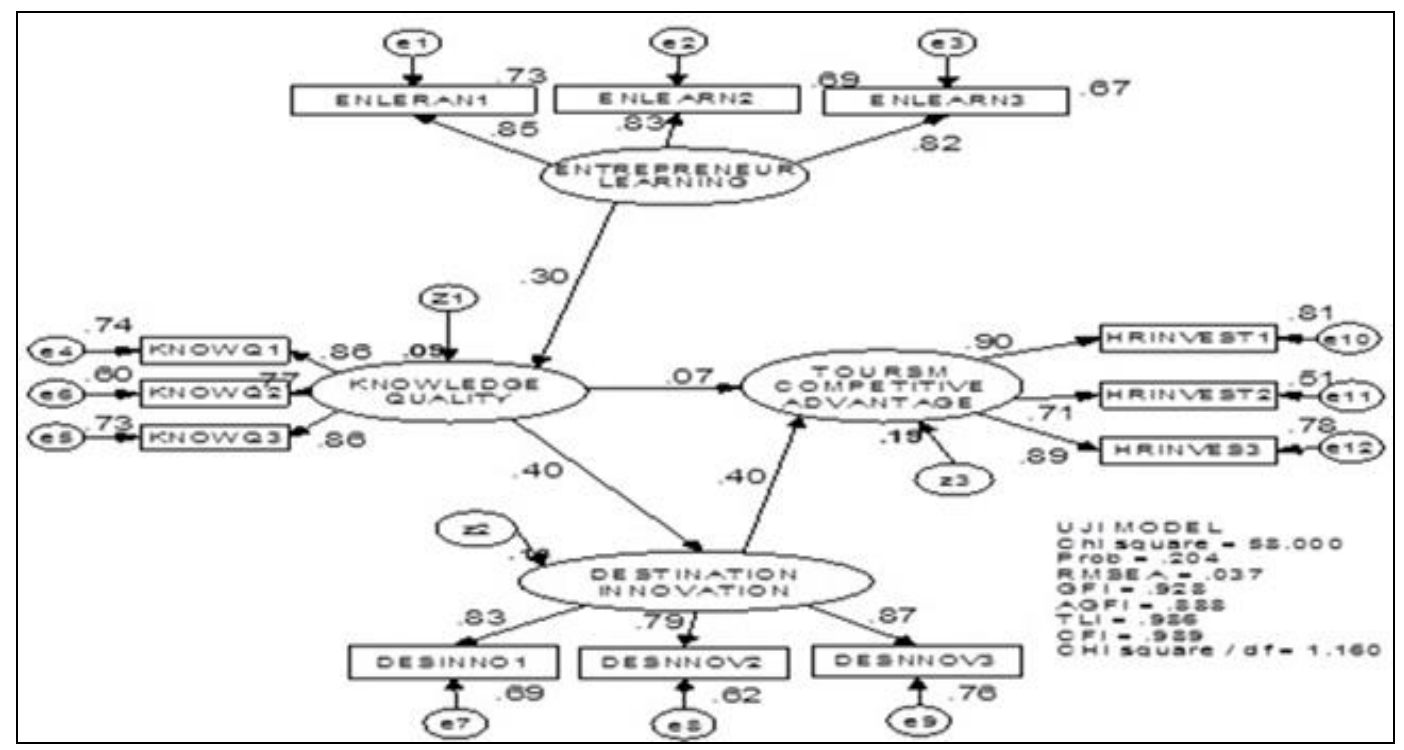

Figure 2. The Results of Full Model Destination Innovation

Table 1 shows that the 3 proposed hypotheses were supported by empirical data and one hypothesis was not supported by empirical data. The first hypothesis proposed was that increasing innovative destinations will enhance competitive tourism and it was supported by empirical data. This condition indicates that the increase in assimilation, differentiation and integration developed will realize environmental sustainability, social wealth and attractiveness. Thus, this supports the study of Foroudi et al., (2016) stating that the capability of innovation is one of the triggers in achieving sustainable competitive advantage. However, the second hypothesis of knowledge quality which was developed as an antecedent to increase destination competitive advantages was not supported by empirical data. This condition is caused by knowledge quality indicators which include adaptable, applicable and expandable have not been carried out 
intensively, extensively and comprehensively. The third hypothesis of knowledge quality which is developed will increase destination innovativeness was supported by empirical data. This condition indicates that increasing adaptable, applicable and expandable indicators will trigger an increase in innovation destination variables with assimilation, differentiation and integration indicators. Thus, it supports the opinion of Monteagudo and Maria (2018) who say knowledge plays an important role in innovation. Innovation in organizations is not possible without the existence of highly qualified human resources, who are proactive towards cooperation and innovation. Meanwhile, the fourth hypothesis states that increasing entrepreneur learning development will lead to an increase in knowledge quality was supported by empirical data. This condition shows that entrepreneur learning with an indicator of ability to recognize opportunities, produce new ideas and take risks which increase will enhance adaptable, applicable and expandable. Thus, this study supports the opinion of Gjedia and Ndou (2019) that entrepreneur learning is a learning process and skills which produce knowledge.

Table 1. Inner Path Model Coefficients and their Significance

\begin{tabular}{|c|c|c|c|c|}
\hline No & Exogenous variable & Endogenous variable & Standard Estimate & T-value \\
\hline 1 & Tourism Competitive Advantage & Destination Innovative & 0.403 & $3.648^{*}$ \\
\hline 2 & Tourism Competitive Advantage & Knowledge Quality & 0.070 & 0.653 \\
\hline 3 & Destination Innovative & Knowledge Quality & 0.404 & $3.943^{*}$ \\
\hline 4 & Knowledge Quality & Entrepreneur Learning & 0.296 & $2.854^{* *}$ \\
\hline & 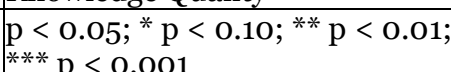 & & & \\
\hline
\end{tabular}

\section{Direct, indirect and total impacts}

The analysis of these direct, indirect and total effects is intended to determine the effects of the hypothesized variables. Direct effect is the coefficient of all coefficient lines with one end arrow or commonly referred to as path coefficient, while indirect effect is the impact caused by moderating variable. Furthermore, the total effect is the total sum of direct and indirect effects. The testing of the direct, indirect and total effects of each variable on the Knowledge Quality Development Model towards Entrepreneurship Learning-Based Organizational Performance is presented in table 2 as follows.

Table 2. Direct, indirect and total impacts

\begin{tabular}{cllccc}
\hline No & Variable & Effect & $\begin{array}{c}\text { Entrepreneur } \\
\text { Learning }\end{array}$ & $\begin{array}{c}\text { Knowledge } \\
\text { Quality }\end{array}$ & $\begin{array}{c}\text { Destination } \\
\text { Innovation }\end{array}$ \\
\hline $\mathbf{1}$ & Knowledge & Direct & 0.296 & 0.000 & 0.000 \\
& Quality & Indirect & 0.000 & 0.000 & 0.000 \\
& Total & 0.296 & 0.000 & 0.000 \\
\hline 2 & Destination & Direct & 0.000 & 0.404 & 0.000 \\
& Innovation & Indirect & 0.120 & 0.000 & 0.000 \\
& Total & 0.120 & 0.404 & 0.000 \\
\hline 3 & Tourism & Direct & 0.000 & 0.070 & 0.403 \\
& Competitive & Indirect & 0.069 & 0.163 & 0.000 \\
& Advantage & Total & $\mathbf{0 . 0 6 9}$ & $\mathbf{0 . 2 3 2}$ & $\mathbf{0 . 4 0 3}$ \\
\hline
\end{tabular}

Table 2 containing the direct, indirect and total effects of tourism competitive advantage models explains that the quality knowledge variable is directly influenced by entrepreneur learning at 0.296 while the indirect effect that affects the quality knowledge variable is not apparent in this research model because the quality knowledge variable is a variable at the first level in a structured equation model. The innovative destination 
variables are directly influenced by knowledge quality with 0.404 while indirect effects which affect innovative destination variables are not seen in this research model because innovative destination variables are variables at the first level in structured equation model. Variables of tourism competitive advantage are directly influenced by quality knowledge (0.070 and destination innovation (0.403). It shows that destination innovative variables have a significant influence on tourism competitive advantage while indirect effects of quality knowledge on innovation through destination variables are o.163. The total effect of entrepreneur learning variables on tourism competitive advantage is 0.069. Meanwhile, Knowledge quality learning for tourism competitive advantage is 0.232. Destination innovation regarding tourism has a competitive advantage of 0.403 . Based on these total effects, we can conclude that the Destination variable towards tourism competitive advantage is $40.3 \%$.

\section{Managerial Implications}

The developed and expanded quality of knowledge has consequences of being able to adapt or being easily applied to tasks. Knowledge must be transformed into action to realize its usefulness and profitability. Unique knowledge is a source of innovative activity. Thus, the possessed quality of knowledge resources must be dynamic in order to realize tourism competitive advantage.

It provides better insight into the potential factors to influence tourism competitive advantage through entrepreneurial learning and knowledge quality and destination innovativeness on non-government and government attractions. There is importance of the knowledge quality factor in achieving destination innovation, and the impact resulted from destination competitive advantages and we need to offer a deeper understanding of important contextual issues which have impacts on efforts to implement strategies of tourism marketing and in turn increase destination competitive advantages. Therefore, the evidence of this model contributes to the theory by extending support for social exchange theory and knowledge management into the context of strategies for tourism marketing and development.

\section{Limitations and Future Research}

The calculation results with Software AMOS show that the effect of knowledge quality has no significant effect on tourism competitive advantage. Based on the limitations of the study of antecedent variables, knowledge quality of competitive tourism advantage is an interesting black bock study area. This research, however, has not considered the quality factor of Human Resource of tourism enterpreneurs who are possibly considered to be able to increase their competitiveness / innovativeness on achieving tourism competitive advantage. The addition of environmental support factors or added value can be considered to vary further researches.

\section{CONCLUSION}

The model of developing tourism competitive advantages can be enhanced through destination innovative which is built with indicators of assimilation, differentiation and integration.

\section{Aknowlegments}

Tourism leaders in Central Java Province who have been willing to become respondents. Then the Tourism Office Central Java province that has supported this study.

\section{REFERENCES}

Abreu-Novais, M., Ruhanen L., Arcodia C. (2016). Destination competitiveness: what we know, what we know but shouldn't and what we don't know but should. Current Issues in Tourism, 19.6 492-512. 
Al Bayrak, T., Caber, M., Rosario, González-Rodríguez, M. \& Aksu, A. (2018). Analysis of destination competitiveness by IPA and IPCA methods: The case of Costa Brava, Spain against Antalya, Turkey. Tourism Management Perspectives, 28, 53-61. doi:10.1016/j.tmp.2018.07.005.

Añaña, Edar da Silva, Raphaella Costa Rodrigues \& da Silva Flores, L.C. (2018). Competitive performance as a substitute for competiveness measurement in tourism destinations: an integrative study. International Journal of Tourism Cities 4.2: 207-219.

Armenski, T., Dwyer, L. \& Pavluković, V. (2018). Destination competitiveness: public and private sector tourism management in Serbia. Journal of Travel Research. 57.3: 384-398.

Aydin, S. \& Dube, M. (2018). Knowledge management, innovation, and competitive advantage: is the relationship in the eye of the beholder. Knowledge Management Research \& Practice, 16.3: 402-413.

Chin, Wei Lee, Haddock-Fraser, Janet \& Hampton, Mark P. (2017). Destination Competitiveness: Evidence from Bali. Current Issues in Tourism, 20 (12). pp. 1265-1289. ISSN 1368-3500.

Choi, Miju, Jin-Soo Lee \& Ava J. Seo. (2018). Shopping destination competitiveness: scale development and validation. Journal of Travel \& Tourism Marketing, 35.8: 1087-1103.

Corte Della, V. \& Aria, M (2016). Coopetition and sustainable competitive advantage. The case of tourist destinations. Tourism Management, 54 524-540.

Chouch G. \& Ricci JR. (1999). Tourism, Competitiveness, and Societal Prosperity. Journal of Business Research. 44 (3): 137-152.

Chow, W.S. \& Chan, L.S. (2008). Social network, social trust and shared goals in organizational knowledge sharing. Information \& management, 45(7), 458-465.

Cowdean, S., Whitby P., Bradley L., McGowan P., (2019). Entrepreneurial learning in practice: The impact of knowledge transfer. Industry \& Higher Education (2019). 0950422218812630.

Davenport, T.H. \& Prusak, L. (1998). Working knowledge: How organizations manage what they know. Harvard Business Press.

Deale, Cynthia S. (2016). Entrepreneurship education in hospitality and tourism: insights from entrepreneurs. Journal of Teaching in Travel \& Tourism, 16. 1: 20-39.

Deale, Cynthia S. \& Seung Hyun L. (2018). Are They on the Same Wavelength? Industry Professionals' and Students' Perceptions of Online Graduate Degree Programs in Hospitality and Tourism. Journal of Hospitality \& Tourism Education, 30.3: 154-166.

Demet, Bagiran O. (2019). Towards a model of destination innovation process: an integrative review. The Service Industries Journal, 39.3-4, 206-228.

Dong Kyoon Yoo., Vonderembse, M.A. \& Ragu-Nathan, T.S. (2011). Knowledge quality: antecedents and consequence in project teams. Journal of Knowledge Management, 15(2), 329-343.

Ernest, K., Somiah K.M., \& Ansah K. S. (2015). Towards Entrepreneurial Learning Competencies: The Perspective of Built Environment Students. Higher Education Studies 5(1).

Fatima, J.K., Ghandforoush, P., Khan, M. \& Masico, R.D. (2017). Role of innovativeness and self-efficacy in tourism m-learning. Tourism Review, 72.3: 344-355.

Fernández-M., Alegre, J. (2015). Entrepreneurial orientation and export intensity: Examining the interplay of organizational learning and innovation. International Business Review, 24(1): 148-156.

Foroudi, P., Gupta, S., Nazarian, A. \& Duda, M. (2017). Digital technology and marketing management capability: achieving growth in SMEs. Qualitative Market Research, An International Journal, 20(2), 230-246.

Gartner, W. B. (1990). What are we talking about when we talk about entrepreneurship? Journal of Business venturing, 5(1), 15-28.

Gallouj, F. \& Savona, M. (2010). Towards a theory of innovation in services: a state of the art. The handbook of innovation and services: A multi-disciplinary perspective, 27-48.

Gjedia, R. \& Ndou, V. (2019). Educating of Entrepreneurship Competence in Pre-university Education System: An Effective Way for Tourism Development and Innovation. Smart Tourism as a Driver for Culture and Sustainability. Springer, Cham, 35-47.

Hall, C.M. (2019). Constructing sustainable tourism development: The 2030 agenda and the managerial ecology of sustainable tourism. Journal of Sustainable Tourism, 1-17. doi:10.1080/09669582.2018.1560456.

Han, John, Gil S. Jo \& Jina Kang. (2018). Is high-quality knowledge always beneficial? Knowledge overlap and innovation performance in technological mergers and acquisitions. Journal of Management \& Organization, 24.2: 258-278.

Hair, Jr., F. Joseph, R. E., Anderson, R.L. Tatham W. C., Black. (1992). Multivariate Data Analysis with Readings, Macmillan.

Hjalager, A.M. (2002). Repairing innovation defectiveness in tourism. Tourism Management, vol. 23, núm. 1, pp. 465-474.

Hjalager, A. M. (2010). A review of innovation research in tourism, Tourism Management, vol. 31, núm. 1, pp. 1-12.

Hunter, Lise \& Jonathan Lean. (2018). Entrepreneurial learning-a social context perspective: evidence from Kenya and Tanzania. Journal of Small Business and Enterprise Development 25.4: 609-627.

Kamya, M.T., Ntayi J.M., \& Ahiauzu, A. (2011). Organisational learning and competitive advantage: testing for the interacting influence of knowledge management and innovation. International Journal of Innovation and Learning, 10.4: 376-401. 
Kane, A. A., Argote, L. \& Levine, J. M. (2005). Knowledge transfer between groups via personnel rotation: Effects of social identity and knowledge quality. Organizational Behavior and Human Decision Processes, 96(1), 56-71. doi:10.1016/j.obhdp.2004.09.002 url to share this paper: scihub.tw/10.1016/j.obhdp.2004.09.002.

Kallmuenzer, A. \& Mike P. (2018). Innovativeness and control mechanisms in tourism and hospitality family firms: A comparative study. International Journal of Hospitality Management, 70: 66-74.

Lawson, B \& Samson. D. (2011). Developing innovation capability in organizations: a dynamic capabilities approach, International Journal of Innovation Management, vol. 5, núm. 3, pp. 377-400.

Lane, P.J. \& Lutbatkin, M. (1998). Relative absorptive capacity and interorganizational learning, Strategic Management Journal, Vol. 19 No. 5, pp. 461-477.

Lee, Kwang-Ho \& Sunghyup Sean Hyun. (2016). The effects of perceived destination ability and destination brand love on tourists' loyalty to post-disaster tourism destinations: The case of Korean tourists to Japan. Journal of Travel \& Tourism Marketing 33.5: 613-627.

Majchrzak, Ann, Lynne P. Cooper \& Olivia E. Neece. (2004). Knowledge reuse for innovation. Management science: $50.2174-188$.

Matthew, Ernest, Kissi, Somiah K. \& Ansah K. Samuel. (2015). Towards Entrepreneurial Learning Competencies: The Perspective of Built Environment Students. Higher Education Studies 5.1: 20-30.

Martínez-Román, Juan A., et al. (2015). Innovativeness and business performances in tourism SMEs. Annals of Tourism Research, 54: 118-135.

Monteagudo, Inmaculada Carrasco \& María Soledad Castaño Martínez. (2015). Drivers of entrepreneurship innovation in tourism sector: entrepreneurship, knowledge and internationalization. Icade: Revista de las Facultades de Derecho y Ciencias Económicas y Empresariales 94: 11-29.

Musetescu, A. (2013). How to achieve a competitive advantage. Knowledge Horizons. Economics, 5, 13.

Neck, Heidi M. \& Andrew C. Corbett. (2018). The scholarship of teaching and learning entrepreneurship. Entrepreneurship Education and Pedagogy 1.1: 8-41.

Nieves, Julia \& Gonzalo Diaz-Meneses. (2018). Knowledge sources and innovation in the hotel industry: Empirical analysis on Gran Canaria Island, a mature mass-tourism destination. International Journal of Contemporary Hospitality Management, 30.6: 2537-2561.

Nonaka, I. \& Takeuchi, H. (1996). A theory of organizational knowledge creation. International Journal of Technology Management, 11(7-8), 833-845.

Politis, Diamanto, \& Jonas Gabrielsson. (2015). Modes of learning and entrepreneurial knowledge. International Journal of Innovation and Learning, 18.1: 101-122.

Sekaran, Uma. (1992). Research Methods for Business: A Skill Building Approach, Second Ed., John Willey \& Sons, Inc.

Sheng, Margaret L. \& Iting Chien. (2016). Rethinking organizational learning orientation on radical and incremental innovation in high-tech firms. Journal of Business Research, 69.6: 2302-2308.

Stinglhamber, F., Marique, G., Caesens, G., Desmette, D., Hansez, I., Hanin, D. \& Bertrand, F. (2015). Employees' organizational identification and affective organizational commitment: An integrative approach. PloS one, 10(4), eo123955.

Sundbo, J., Orfila-Sintes, F. \& Sørensen, F. (2007). The innovative behaviour of tourism firms - comparative studies of Denmark and Spain. Research Policy, 36(1), 88-106.

Valaei, Naser \& Sajad Rezaei. (2016). Job satisfaction and organizational commitment: An empirical investigation among ICT-SMEs. Management Research Review 39.12: 1663-1694.

Waheed, Mehwish \& Kiran Kaur. (2016). Knowledge quality: A review and a revised conceptual model. Information Development 32.3: 271-284.

Waheed, Mehwish, Kiran Kaur \& Atika Qazi. (2016). Students' perspective on knowledge quality in eLearning context: a qualitative assessment. Internet Research 26.1 120-145.

Wang, Wei, Shu T. Cole \& Joseph S. Chen. (2018). Tourist innovation in Air travel. Journal of Travel Research, 57.2: 164-177.

Wang, Catherine L. \& Harveen Chugh. Entrepreneurial learning: past research and future challenges. Entrepreneurial learning. Routledge, 2015. 11-44.

Widodo, Sitty Yuwaliatin \& Endang Dwi Astuti (2015). The Development Design of Knowledge quality Based on Knowledge networking and Cross Functional Integration Toward SMES' Innovative Performance. Journal of Applied Economic Sciences (JAES), Volume X, Issue 8 (38).

Wong, P.P.W. (2015). Role of components of destination competitiveness in the relationship between customerbased brand equity and destination loyalty. Current Issues in Tourism, 21(5), 504-528, doi: 10.1080 /13683500. 2015.1092949.

Zach, F. J. \& Hill, T. L. (2017). Network, knowledge and relationship impacts on innovation in tourism destinations. Tourism Management, 62, 196-207.

Zehrer, A., Muskat, B., \& Muskat, M. (2015). Enablers of corporate innovation in tourism. In: Pechlaner, H., \& Innerhofer, E. (eds.), Competence-Based Innovation in Hospitality and Tourism (pp. in print). Gower Publishing. 